DOI: https://doi.org/10.47405/mjssh.v6i11.1139

\begin{tabular}{|c|c|}
\hline & Malaysian Journal of Social Sciences and Humanities (MJSSH) \\
\hline Malaysian Journal of & Volume 6, Issue 11, November 2021 \\
\hline (MJ-ssH) & e-ISSN : 2504-8562 \\
\hline & $\begin{array}{l}\text { Journal home page: } \\
\text { www.msocialsciences.com }\end{array}$ \\
\hline
\end{tabular}

\title{
Dari Federalisme Terpusat ke Federalisme Multi-etnik: Pengaruh Etnisiti dalam Persekutuan Malaysia
}

\author{
Abdul Aqmar Ahmad Tajudin', Muhamad Nadzri Mohamed Noor ${ }^{1}$, Hussain Yusri Zawawi² \\ 1Fakulti Sains Sosial dan Kemanusiaan, Universiti Kebangsaan Malaysia (UKM), Malaysia \\ ${ }^{2}$ Fakulti Undang-Undang dan Hubungan Antarabangsa, Universiti Sultan Zainal Abidin (UniSZA), Malaysia
}

Correspondence: Muhamad Nadzri Mohamed Noor (nadzri@ukm.edu.my)

\begin{abstract}
Abstrak
Kesusasteraan lepas cenderung melihat federalisme Malaysia dibentuk oleh faktor sejarah dan penjajahan. Oleh kerana itulah mereka selalu membahagikan perbincangan mereka di dalam federalisme Malaysia kepada tiga tahap perkembangan iaitu kolonialisme, dekolonialisme dan pascakolonialisme. Berbeza dari kajian terdahulu, artikel ini cuba melihat dan meneroka pengaruh etnisiti dalam pencorakan perkembangan federalisme Malaysia. Semasa proses dekolonisasi, etnisiti menjadi antara angkubah utama yang dipertimbang oleh Suruhanjaya Reid dalam menggubal perlembagaan Persekutuan Malaya 1957 yang agak terpusat bagi mengekalkan identiti Melayu, Islam dan kedudukan Raja-raja Melayu. Semasa pembentukan Persekutuan Malaysia pada tahun 1963 pula, etnisiti turut mempengaruhi rekayasa struktur persekutuan yang asimetrikal. Tujuannya adalah bagi memastikan identiti dan autonomi etnik di Sabah dan Sarawak terpelihara kerana tanpa jaminan ini, Sabah dan Sarawak sukar untuk bersetuju untuk membentuk Persekutuan Malaysia. Selepas rusuhan kaum pada tahun 1969 sehingga politik kontemporari kini, pengaruh etnisiti telah mencorakkan Malaysia sebagai federalisme multi-etnik. Ini dapat dilihat dengan wujudnya kebangkitan nasionalisme etnik majoriti, perdebatan mengenai asimilasi dan integrasi etnik, tuntutan perlembagaan yang lebih simetri antara pusat-negeri, persaingan etnik antara Melayu dan bukan Melayu di Semenanjung, antara Muslim Bumiputera dan bukan Muslim Bumiputera di Sabah dan Sarawak dan pertentangan antara kumpulan agama konservatif dalam progresif. Justeru, pengaruh etnisiti yang kuat ini berupaya menjejaskan matlamat serampang dua mata federalisme multi-etnik di Malaysia, iaitu mengiktiraf kepelbagaian (diversity) dan mewujudkan perpaduan (unity) kerana ia terus mengekalkan sifat tegang tetapi stabil dalam kalangan masyarakatnya. Pun begitu, artikel ini melihat struktur federalismenya yang bersifat terpusat, asimetri dan multi-etnik inilah yang menyumbang kepada kestabilan sosio-politik dan integriti persekutuan Malaysia.
\end{abstract}

Kata kunci: etnisiti, federalisme, kestabilan politik, Malaysia, nasionalisme etnik

\section{From Centralised, to Multiethnic Federalism: The Influence of Ethnicity in the Malaysian Federation}

\begin{abstract}
Past literature in Malaysian federalism tend to argue that the state is constructed by historical factors and colonialism. As the results, they have the propensity to organise their dicussions in a rather cliché division of three eras, namely colonialism, decolonisation and post-colonial. In contrast, this article attempts to explore the influence of culture particularly ethnisity in the making and development of
\end{abstract}


Malaysian federalism. During the Malayan decolonization, ethnicity was among the main variables considered by the Reid Commission in drafting the independent constitution of Malaya. It was significantly made centralised in conserving the Malay identity, Islam and the position of the Malay Rulers. Later, in the formation on Federation of Malaysia in 1963, ethno-cultural factor once again shaped the assymetrical nature of the new state. Its purpose was to guarantee the ethno-regional autonomy for Sabah and Sarawak in which without it, both of these territories would be hesitant to form the federation. Since the 13 May 1969 racial clashes to date, the ethnicity has shaped Malaysia as a pluri-national (or multi-ethnic) federalisme. This can be observed with the rise of majoritarian nationalism, the debates on the model in how to unite the populace - between assimilation versus integration, ethnic competitions between Malays and Non-Malays in the peninsular and Muslim natives and Non-Muslim natives in Sabah and Sarawak, and the constestations among progressive and conservative Muslims. The salience of ethnicity in the formation and development of the federation might have compromised the two-pronged objectives of its multiethnic federalism - which is to recognise diversity and build unity as it continues to bring about tense (albeit stable) in the ethnic relations among the populace. Nevertheless, this article observes that the nature of the centralised, assymetrical and multi-ethnic Malaysian federalism was significant to the socio-political stability in, and the integrity of the federation.

Keywords: ethnic nationalism, ethnicity, federalism, Malaysia, political stability

\section{Pengenalan}

Bhattacharyya (2010), Harding dan Chin (2014) serta Fong (2016) telah membahagikan pembentukan Persekutuan Malaysia kepada tiga peringkat, iaitu peringkat kolonialisme (1895; 1948), dekolonialisme (1957) dan pasca-kolonialisme (1963). Mereka sepakat menyatakan peringkat kolonialisme merupakan asas utama dalam federalisme Malaysia kerana tempoh ini adalah tempoh awal British memperkenalkan Malaysia dengan sistem federal apabila British menyatukan empat negeri-negeri Melayu, iaitu Perak, Selangor, Pahang dan Negeri Sembilan sebagai Negeri-Negeri Melayu Bersekutu pada tahun 1895. Pada tahun 1948 pula, British menggabungkannya dengan lima lagi negeri Melayu (Johor, Kelantan, Terengganu, Kedah dan Perlis) dan dua negeri jajahan British (Penang dan Melaka) untuk membentuk Persekutuan Malaya. Hal ini menyediakan Malaya sebuah perlembagaan persekutuan yang memusatkan seluruh bidang kuasa utama kepada Pesuruhjaya Tinggi kecuali dalam bidang agama Islam dan adat Melayu.

Semasa dekolonialisasi pula, iaitu dari pasca Perang Dunia Kedua hingga kemerdekaan Malaysia pada tahun 1957, struktur persekutuannya tidak banyak berubah, malah pemusatan kuasa semakin meningkat apabila kerajaan pusat bukan hanya menguasai bidang kuasa signifikan seperti kewangan, pertahanan, hubungan luar, pendidikan, dan kesihatan, tetapi juga boleh menggubal undang-undang di bawah bidang kuasa kerajaan negeri. Dalam era pasca-kolonialisme pula, wujud usaha pengembangan persekutuan dengan termeterainya Perjanjian Malaysia 1963 yang menggabungkan Singapura, Sabah dan Sarawak dalam pembentukan Persekutuan Malaysia.

Perbincangan para sarjana yang melihat perkembangan federalisme Malaysia dari aspek kronologi dan historikalnya adalah menarik, namun, berbeza dengan kajian sebelum ini yang melihat perkembangan federalisme Malaysia dari aspek historikal dan legalistik, artikel ini pula meneroka perkembangannya dari aspek etnisiti berdasarkan bentuk perkembangan federalisme yang dilaluinya, iaitu federalisme terpusat (a centralised federal state), federalisme asimetri (an asymmetrical federal state), dan federalisme multi-etnik (a multinational federal state).

\section{Federalisme dan Etnisiti}

Di dalam kerangka perbincangan federalisme, perhatian terhadap aspek etnisiti semakin meningkat lewat ini kerana konflik dan persaingan etnik masih ketara meskipun dalam era globalisasi kini. Di 
Belgium, persaingan etnik berlaku antara kumpulan etnik yang berbahasa Belanda dengan yang berbahasa Perancis. Di Nigeria pula, persaingan etnik berlaku antara etnik Hausa-Fulani yang beragama Islam dengan etnik Yoruba yang beragama Kristian. Manakala di Ethiopia, persaingan berlaku antara etnik utama seperti Oromo dan Amhara dengan etnik minoriti Tigray kerana etnik minoriti Tigray menguasai jawatan utama pentadbiran negara. Malah di Sudan adalah lebih serius apabila tercetusnya konflik etno-agama yang akhirnya memecahkan Sudan kepada Sudan Utara dan Sudan Selatan pada tahun 2011. Seperti negara-negara di atas, Malaysia juga berhadapan dengan isu konflik dan persaingan etnik, khususnya antara Melayu dengan bukan Melayu serta Muslim Bumiputera dengan bukan Muslim Bumiputera di Sabah dan Sarawak.

Dalam mengurus cabaran-cabaran ini, beberapa sarjana telah memperkenalkan konsep federalisme multi-etnik. Pinder (2007:1) menyatakan tujuan federalisme multi etnik ini adalah untuk menyediakan "a framework that can accommodate and as far as possible resolve some of the most intractable political conflicts of our time: those that stem from competing national visions, whether within or between established states." Adeney dan Bhattacharrya (2018:410) pula menyatakan federalisme multi-etnik adalah "the boundaries of the internal units are drawn in such a way that at least some of them are controlled by national or ethnic minorities." Ini menunjukkan federalisme multi-etnik adalah sebuah sistem pemerintahan yang bertujuan untuk menampung perbezaan etnik, iaitu agama, bahasa dan budaya melalui struktur dan institusi federalnya bagi mencapai dua matlamat utama, iaitu untuk mengiktiraf kerencaman etnik dan bagi mendorong semangat perpaduan dalam kepelbagaian.

Bagaimana pula dengan keadaannya Malaysia? Berdasarkan premis ini, artikel ini mengguna pakai konsep federalisme multi-etnik sebagai alat analisis bagi meneroka pengaruh etnisiti dalam merefleksi perkembangan federalisme Malaysia dari sudut budaya.

\section{Debat Federalisme di Malaysia}

Loh (2010), Wong dan Chin (2011) serta Case (2016) melihat pembentukan dan perkembangan federalisme Malaysia sebagai a centralised federal state. Loh mengkritik federalisme Malaysia sebagai persekutuan yang sangat terpusat. Wong \& Chin pula mendefinisikan Malaysia sebagai $a$ centralised parliamentary federalism characterised by one-party dominance. Case juga menyatakan "...federalism in Malaysia is highly centralized, with most powers over important areas of policy making and revenue raising held by the central government". Mereka umumnya sepakat dalam menyatakan perlembagaan 1957 digubal dengan memberi kuasa yang banyak kepada kerajaan pusat manakala kerajaan negeri hanya diperuntukkan bidang kuasa yang terhad. Selain itu, perlembagaan juga membenarkan kerajaan pusat mencampuri urusan negeri melalui tiga perkara, iaitu Perkara 75 bagi tujuan keselarasan undang-undang negeri dengan undang-undang persekutuan, Perkara 76(4) bagi tujuan keseragaman undang-undang dan dasar, Perkara 91 tentang Kanun Tanah Negara, dan Perkara 95A tentang penubuhan Akta Kerajaan Tempatan.

Salleh, Puyok dan Bagang (2019) serta Chin (2019) pula antara sarjana yang menulis tentang Malaysia sebagai an asymmetrical federal state. Mereka mendapati ciri asimetri dapat dilihat daripada tiga dokumen iaitu the 20-points, 18-points dan Malaysia Agreement 1963 (MA63). Umumnya, dokumen tersebut menjamin perlindungan identiti, kebebasan kewangan dan autonomi negeri Sabah dan Sarawak bagi mengurus pentadbirannya. Selain itu, terdapat beberapa lagi tambahan perlindungan kepada Sabah dan Sarawak seperti Bahagian XIIA (Perlindungan Tambahan kepada Sabah dan Sarawak) yang menyatakan berbanding bahasa Melayu, Sabah dan Sarawak boleh menggunakan bahasa Inggeris untuk urusan rasmi dalam Dewan Undangan Negeri dan sidang mahkamah. Di samping itu, Perkara 161B juga mengehadkan bukan pemastautin hak untuk melakukan amalan perundangan di mahkamah di mana peguam daripada negeri lain tidak dibenarkan untuk mengamalkan guaman mereka di dua negeri ini tanpa terlebih dahulu mendapatkan permit dan kebenaran. Selain itu, Sabah dan Sarawak juga mempunyai kawalan eksklusif terhadap autoriti imigresennya di mana penduduk daripada unit persekutuan lain perlu mempunyai dokumen perjalanan. 
Kajian tentang Malaysia sebagai a multinational federal state adalah sangat terhad dan Bakar (2007) dilihat satu-satunya sarjana yang menulis tentang hal ini. Beliau menggariskan beberapa peruntukan perlembagaan yang menjadikan Malaysia sebagai sebuah persekutuan multi etnik. Antaranya adalah Perkara 160 berkaitan dengan takrifan etnik Melayu yang mesti seorang yang beragama Islam, bercakap Bahasa Melayu, dan mengamalkan adat Melayu serta Perkara 161A(6) tentang etnik Bumiputera di Sabah dan Sarawak. Selain itu adalah Perkara 153 tentang kedudukan istimewa orang Melayu dan Bumiputera, Perkara 3 yang menetapkan Islam sebagai agama rasmi persekutuan Malaysia, Perkara 152(1) yang meletakkan Bahasa Melayu sebagai bahasa kebangsaan. Baginya, peruntukan perlembagaan ini telah mewujudkan konflik etnik dalam tiga dimensi, iaitu konflik antara Melayu dengan bukan Melayu, antara konservatif dan progresif agama di bahagian Semenanjung, dan antara Bumiputera Islam dan Bumiputera bukan Islam di Sabah dan Sarawak. Konflik ini berlaku disebabkan wujudnya sentimen etnik yang memunculkan sifat multi-ethnic, multi-religion, multilinguistic dan multi-cultural.

Perbincangan perkembangan federalisme Malaysia daripada federalisme terpusat, federalisme asimetri dan federalisme multi-etnik adalah menarik, namun perbincangan perkembangan federalisme tersebut hanya tertumpu kepada aspek legalistik, sedangkan perkembangan ketiga-tiga bentuk federalisme tersebut turut berkait dengan pengaruh etnisiti. Justeru artikel ini cuba untuk mengisi kelompangan ini.

\section{Malaysia Sebagai Federalisme Terpusat}

Pertimbangan dan persaingan etnisiti jelas terlihat selepas Malaysia mengalami transisi daripada masyarakat mono-etnik kepada masyarakat multi-etnik hasil pengenalan dasar dan polisi ekonomi kolonialisme Barat seperti yang dibincangkan dalam bahagian di atas. Misalnya, sehingga tahun 1947, sebelum terbentuknya persekutuan Malaysia yang pertama pada tahun 1948 (Perjanjian Persekutuan Tanah Melayu 1948), etnik Melayu berkomposisi sebanyak 2,130,493 orang, Cina 1,880,452 orang, India 553,961 orang, dan lain-lain etnik nasional 264,630 orang (Morrison, 1949:240). Justeru dengan perubahan komposisi masyarakat sebegini, sarjana awal politik Malaysia seperti Simandjuntak (1969) mendapati bahawa etnik Melayu yang berkomposisi majoriti tetap melihat kumpulan etnik mereka sebagai 'the original sons of the soil' atau 'the first nation' yang telah menduduki Malaysia sejak awal era Kesultanan Melaka pada abad ke-15. Pernyataan ini menunjukkan bahawa biarpun jumlah etnik bukan Melayu/Bumiputera semakin meningkat, namun nilai dan identiti etnik Melayu/Bumiputera yang didakwa sebagai bangsa terawal mendiami Malaysia dilihat mereka sebagai perlu disedari dan dihormati oleh kumpulan etnik bukan Melayu/Bumiputera.

Justeru selepas tamatnya Perang Dunia Kedua, prinsip 'Malay cultural dominance' ini telah mula meningkatkan sentimen nasionalisme Melayu yang berperanan menjadikan Malaysia sebagai sebuah persekutuan terpusat. Pun begitu, orientasi atau dominasi nilai dan identiti etnik Melayu awalnya cuba diketepikan dalam pembentukan sistem pemerintahan Malaysia pada era kolonialisme. Misalnya, pada tahun 1946, British memperkenalkan Malayan Union, sebuah gabungan pemerintahan unitari negerinegeri Melayu dengan kerakyatan mudah dan sama rata tanpa mengira etnik dan keturunan dan sektor perkhidmatan awam turut dibuka kepada bukan Melayu. Malah, perlembagaan Malayan Union juga mengurangkan kedaulatan dan kuasa Sultan-sultan Melayu terhadap negeri masing-masing di mana kuasa baginda hanya terhad dalam soal agama Islam dan adat istiadat dalam negeri sahaja. Pengetepian nilai dan identiti Melayu sebagai pertimbangan utama dalam pemerintahan negara pada ketika itu telah mencetuskan provokasi dan kemarahan orang Melayu kerana mereka berasakan peruntukan kerakyatan yang saksama tidak mencerminkan pengiktirafan terhadap status Melayu yang merupakan etnik asal di Tanah Melayu (Crouch, 1996).

Kemarahan etnik Melayu terhadap kelangsungan hidup mereka akhirnya diterjemahkan melalui penentangan. Penentangan etnik Melayu semakin memuncak apabila munculnya kebangkitan para nasionalis Melayu untuk memobilisasi gerakan bagi menghalang tindakan British yang dilihat menggugat maruah mereka sebagai penduduk asal Tanah Melayu. Kesedaran inilah mewujudkan UMNO yang bergerak secara sistematik, komited dan konsisten menentang penubuhan Malayan Union. Hasil gerakan kebangkitan sentimen nasionalisme Melayu ini, British akhirnya membatalkan 
perlembagaan Malayan Union dan menggantikannya dengan Perjanjian Persekutuan Tanah Melayu 1948. Menariknya, dalam perjanjian ini, British mula peka dan mengambil pengajaran daripada peristiwa penentangan orang Melayu. Contohnya, soal kerakyatan yang sebelum ini diberikan secara terbuka dan saksama, kini telah diperketatkan. Misalnya, pemberian kerakyatan secara permohonan memperuntukkan bahawa seseorang boleh menjadi warganegara sekiranya, pertama, dilahirkan di Persekutuan Tanah Melayu dan telah tinggal sekurang-kurangnya lapan tahun daripada 12 tahun sebelum permohonan dibuat dan kedua, telah tinggal di Persekutuan Tanah Melayu selama 15 tahun daripada 20 tahun sebelum membuat permohonan (Chakraborti, 1996). Malah, apa yang menunjukkan wujudnya penghormatan dan keutamaan prinsip 'Malay cultural dominance' adalah kerakyatan secara permohonan turut menetapkan bahawa selain pemohon perlu berkelakuan baik, bersumpah taat setia dan menjelaskan tujuannya untuk menetap di Persekutuan Tanah Melayu, mereka juga perlu mengetahui bahasa Melayu atau bahasa Inggeris dengan baik (Milne \& Mauzy, 1978).

Pengaruh etnisiti Melayu dalam Persekutuan Tanah Melayu 1948 tidak terhad dalam konteks mobilisasi penentangan dan perjuangan UMNO sahaja, malah keutamaan nilai dan identiti Melayu turut terlihat dalam perjuangan gabungan Pusat Tenaga Rakyat (PUTERA) dan Majlis Tindakan Bersama Seluruh Tanah Melayu (All Malayan Council of Joint Action, AMCJA). Menurut Yeo (1973), PUTERA-AMCJA merupakan gabungan multi etnik pertama di Tanah Melayu yang menentang Perlembagaan Persekutuan Tanah Melayu 1948 atas sebab perlembagaan tersebut hanya memperuntukkan kepentingan bagi orang Melayu sahaja, mereka tidak dilibatkan bersama dalam perbincangan merangka perlembagaan, tiadanya wakil daripada etnik bukan Melayu dan mendakwa perlembagaan tersebut bersifat berat sebelah kerana tidak mewakili semua kaum di Tanah Melayu. Atas alasan tersebut, mereka menuntut perlembagaan itu dibatalkan dan mengusulkan sebuah perlembagaan baharu yang dikenali sebagai 'Perlembagaan Rakyat' atau The People's Constitution pada bulan Oktober 1947 sebagai ganti (Tan, 1995). Namun, apa yang membezakan pengaruh etnisiti Melayu dalam perjuangan UMNO dengan PUTERA-AMCJA adalah jika UMNO memperjuangkan 'Malay cultural dominance' dengan keutamaan kepada nilai dan identiti Melayu, PUTERA-AMCJA pula lebih memperjuangkan penubuhan 'asimilasi Melayu' daripada sudut kerakyatan kerana cadangan kedua-dua pertubuhan ini, selain menggariskan hal ehwal luar negeri dan pertahanan negara perlu menjadi tanggungjawab bersama kerajaan Tanah Melayu dan Kerajaan British dan warna bendera kebangsaan pula perlu mempunyai warna-warna kebangsaan Melayu, iaitu merah dan putih, gabungan tersebut juga mencadangkan bahawa istilah 'Melayu' perlu menjadi gelaran untuk sebarang kewarganegaraan dan taraf nasional di Tanah Melayu beserta dengan Bahasa Melayu sebagai bahasa rasmi negara (Ishak Saat, 2010).

Pengaruh nilai dan identiti Melayu semakin berkembang kuat sewaktu berlakunya rundingan kemerdekaan membentuk Persekutuan Tanah Melayu 1957. Misalnya, menurut Shafruddin (1987), di peringkat awal pembentukannya, PAS mencadangkan Pulau Pinang dan Melaka, iaitu dua negeri yang mempunyai majoriti etnik Cina diubah menjadi negeri Melayu agar kedudukan istimewa etnik Melayu dinikmati bersama oleh dua negeri. Selain itu, PAS juga mencadangkan agar Pulau Pinang dan Melaka mempunyai Raja Melayu seperti sembilan Negeri Melayu yang lain bagi memastikan kedudukan istimewa orang Melayu dapat dilindungi sepenuhnya. Walaupun begitu, terdapat juga pertimbangan etnisiti Melayu yang digunakan sebagai alasan untuk tidak menyokong penubuhan persekutuan 1957. Misalnya, Sultan Johor ketika itu, Sultan Ibrahim menolak idea persekutuan 1957 kerana menjejaskan pentadbiran negeri Johor disebabkan pembentukan persekutuan menandakan berakhirnya peranan penasihat British yang selama ini telah membantu melicinkan pentadbiran negeri Johor (Shafruddin, 1987). Begitu juga di Kelantan, di mana Nik Mohamad Abdul Majid, ketua pertubuhan Kelantan Malay United Front (KMUF) turut menyatakan penubuhan persekutuan 1957 menandakan hilangnya hak dan kedudukan istimewa orang Melayu kepada etnik Cina. Justeru, penentangan dan kebimbangan terhadap penubuhan persekutuan 1957 ini menggambarkan pertubuhan Melayu seperti KMUF amat mengutamakan nilai ketertinggian adat budaya Melayu yang perlu dipelihara, dihormati, dan diangkat dalam perlembagaan.

Dinamika dan pengaruh etnisiti semakin memuncak apabila Suruhanjaya Reid ditugaskan untuk merangka Perlembagaan Persekutuan Tanah Melayu 1957. Pun begitu, prinsip 'Malay cultural dominance' tetap menjadi pertimbangan utama yang menyaksikan nilai dan identiti Melayu dilihat 
mempengaruhi peruntukan perlembagaan persekutuan. Justeru peringkat ini merupakan fasa paling penting kepada Parti Perikatan (UMNO, MCA, dan MIC) umumnya, etnik Melayu yang diwakili UMNO, dan Suruhanjaya Reid untuk mengadakan tuntutan, tawar-menawar, rundingan, dan toleransi yang menguntungkan semua pihak terlibat. Jika tidak, penentangan khususnya daripada orang Melayu seperti mana peristiwa penentangan lalu akan lebih menguat dengan skala yang lebih besar. Milne dan Mauzy (1978:37) berhujah bahawa, "The decision to form a federation was almost certainly dictated by the existence of the Rulers and by the desire to avoid a repetition of protests similar to those voiced against the Malayan Union scheme of 1946." Bagi mengelak kejadian itu berlaku kembali, selain memberi cadangan dalam perlembagaan, Suruhanjaya Reid juga memberi ruang seluasnya kepada setiap perwakilan untuk mengemukakan tuntutan mereka dalam perlembagaan negara. Namun, isu berkaitan hak dan kedudukan etnik tetap mendapat tempat dan mendominasi rundingan kerana setiap perwakilan etnik berdebat mengenai isu perkauman seperti kerakyatan, kedudukan istimewa etnik Melayu, bahasa, dan agama.

Justeru setelah rundingan berkaitan hak dan kedudukan setiap kumpulan etnik berjaya mendapat persepakatan perwakilan etnik, rundingan tentang struktur pemerintahan, pembahagian kuasa antara kerajaan pusat dan kerajaan negeri, serta kedudukan Raja-raja Melayu kurang menimbulkan pertikaian. Ini kerana pengiktirafan 'Malay cultural dominance' oleh bukan Melayu seperti jaminan kedudukan istimewa Melayu, Bahasa Melayu sebagai bahasa rasmi persekutuan, dan agama Islam sebagai agama rasmi persekutuan telah mewujudkan sebuah pengiktirafan quid pro quo apabila bukan Melayu secara timbal balik mendapat hak kerakyatan di samping akomodasi perlembagaan yang membenarkan mereka mengamalkan adat, budaya dan agama masing-masing selari dengan peruntukan perlembagaan. Malah, cadangan Suruhanjaya Reid agar wujudnya sebuah persekutuan dengan "a strong central government with States enjoying a measure of autonomy" turut mendapat persetujuan (Rudner, 1976:496). Maka, mengambil kira latar historikal etnik Melayu sebagai 'sons of soil', demografi majoritinya dan kedudukan istimewa yang dijamin oleh perlembagaan, justeru Rudner (1976) melihat cadangan mewujudkan kerajaan pusat yang kuat bersama-sama dengan etnik Melayu sebagai simbol dan identiti nasional adalah suatu keperluan bagi membentuk sebuah pemerintahan yang berasaskan politi Melayu (Malay polity) dan pemerintahan yang diterajui oleh kepimpinan Melayu (Malay-led government). Disebabkan inilah, kerajaan pusat diperuntukkan bidang-bidang kuasa utama bagi memastikan polisi kerajaan tidak hanya bersifat seragam dengan menjadi rujukan utama bagi pembuatan dasar oleh kerajaan negeri (Ang \& Whiting, 2014), malah penguasaan kerajaan pusat dalam bidang-bidang utama dilihat bagi memastikan nilai, identiti, dan hal ehwal etnik Melayu sebagai etnik majoriti terpelihara tanpa mengetepikan kesejahteraan etnik lain.

Justeru 'Malay cultural dominance' melalui pemusatan kuasa kerajaan pusat ini dilihat cenderung bertujuan untuk mewujudkan kestabilan persekutuan. Oleh sebab itulah, sifat pemusatan kuasa kerajaan pusat kurang mendapat pertentangan dan bangkangan ke arah desentralisasi kuasa oleh unit negerinya. Jika perubahan ini terhalang disebabkan kerumitan proses perlembagaan yang memperuntukkan perlunya sokongan majoriti dua pertiga bagi meminda perlembagaan persekutuan, namun sejarah politik Malaysia merekodkan bahawa BN pernah menjadi kerajaan pusat yang dominan di samping memperoleh majoriti dua pertiga kerusi dewan rakyat sejak merdeka di setiap pilihan raya (kecuali PRU 1969) sehingga PRU 2008. Namun dalam tempoh itu, sistem politik persekutuan Malaysia terus kekal sebagai federalisme terpusat dengan kerajaan pusat yang kuat. Hal ini menunjukkan bahawa selagi mana persekutuan Malaysia mengekalkan nilai dan identiti etnik seperti Raja-raja Melayu sebagai ketua negara, kepimpinan Melayu sebagai ketua kerajaan, Islam sebagai agama rasmi persekutuan, Bahasa Melayu sebagai bahasa kebangsaan, tradisi kemelayuan sebagai simbol autoriti dan legitimasi pentadbiran di samping tidak mendiskriminasikan nilai dan identiti bukan Melayu, maka sifat terpusat dalam federalisme Malaysia dilihat akan terus berlangsung tanpa banyak bantahan khasnya dari etnik majoriti.

\section{Malaysia sebagai Federalisme Asimetri}

Menurut Tarlton (1965:867), beliau menyatakan, "What I mean by symmetry is the level of conformity and commonality in the relations of each separate political unit of the system to both the system as a 
whole and to the other component units." Pernyataan ini menjelaskan bahawa simetri merupakan suatu kesamaan atau keseragaman kuasa dan hubungan antara unit-unit persekutuan. Justeru daripada definisi ini, maka makna konsep asimetri pula adalah berlawanan dengan simetri, yang merujuk kepada ketidaksamaan atau ketidakseragaman kuasa dan hubungan antara unit-unit persekutuan. Dalam perbincangan tentang konsep federalisme asimetri, Watts pula membahagikannya kepada dua jenis. Pertama adalah apa yang dikatakan sebagai asimetri politik. Menurutnyaya, “...political asymmetry, arises from the impact of cultural, economic, social and political conditions affecting the relative power, influence and relations of different regional units with each other and with the federal government" (Watts, 2008:125). Kedua pula adalah asimetri perlembagaan. Pada beliau, "Constitutional asymmetry refers specifically to differences in the status or legislative and executive powers assigned by the constitution to the different regional units" (Watts, 2008:127). Maka, bagaimanakah etnisiti mempengaruhi pembentukan federalisme asimetri di Malaysia? Bagaimanakah pula jenis federalisme asimetri di Malaysia? Adakah ianya berbentuk politik (political asymmetry) atau perlembagaan (constitutional asymmetry)?

Sebelum membincangkan pengaruh dan dinamika identiti Sabah dan Sarawak terhadap pembentukan federalisme asimetri di Malaysia, perlu ditegaskan bahawa antara faktor utama lain yang membawa kepada cadangan perluasan Persekutuan Tanah Melayu ke arah penubuhan 'Gagasan Malaysia' (Persekutuan Tanah Melayu, Singapura, Sabah, Sarawak, dan Brunei) oleh Tunku Abdul Rahman adalah keselamatan dan pertahanan, khususnya bagi menghalang ancaman dan pengaruh komunis. Namun begitu, usaha pembentukan gagasan baharu berhadapan dengan satu cabaran utama, iaitu ke arah menyeimbangkan komposisi kaum. Menjelaskan hal ini, Mohamad Rodzi (2003:110) memetik pernyataan Tunku Abdul Rahman:

"Ifelt then that the condition prevailing in Singapore, the trend of thought and the
sentiments of the people of Singapore were entirely different from us in the
federation. The predominantly Chinese population in Singapore almost make the
island a Little China, and therefore the inclination of certains sections of the
Singapore people is to follow closely the trend of political thinking in China."

Pernyataan Tunku Abdul Rahman menggambarkan kebimbangan awalnya terhadap implikasi penyertaan Singapura dalam penubuhan Malaysia mengambil kira majoriti penduduk Singapura, iaitu sekitar $85 \%$ adalah etnik Cina yang mempunyai kesetiaan tinggi terhadap Tanah Besar China (Mohamad Rodzi, 2003:109). Malah, apa yang lebih menggusarkan beliau adalah kebanyakan etnik Cina di Singapura dilihat bersifat chauvinistik dan merupakan pendukung kuat Parti Komunis Malaya (Fong, 2016). Justeru implikasinya bukan sahaja mengancam keselamatan Tanah Melayu, malah bagi Burgess (2006:92), "...the inclusion of its predominantly Chinese population would have relegated the Malays to a minority and both its economic interests and political leadership were sources of concern to the Malays." Situasi ini cenderung menjadi lebih buruk melihat kepada kurangnya keharmonian hubungan antara etnik Melayu dan Cina yang berlaku khususnya pada era kependudukan Jepun pada tahun 1941. Justeru, bagi Tunku Abdul Rahman, "he and his colleagues would never consider a merger between Malaya and Singapore alone because of the "Chinese problem" (Harding \& Chin, 2014:133).

Tunku Abdul Rahman hanya bersetuju apabila penggabungan Persekutuan Tanah Melayu dan Singapura disertai bersama dengan penyertaan Wilayah Borneo khususnya Sabah dan Sarawak. Ini kerana penyertaan Sabah dan Sarawak dengan penduduk asalnya dapat menyeimbangkan komposisi majoriti etnik Cina di Singapura. Bagi membuktikan hal ini, Mohammad Agus (2006:60-61) menyatakan jika penggabungan ini hanya berlaku antara Persekutuan Tanah Melayu dan Singapura sahaja, maka etnik Cina $(3,424,352)$ akan melebihi etnik Melayu $(3,322,533)$, manakala dengan penyertaan Sabah dan Sarawak, maka ia akan meningkatkan populasi Bumiputera sebanyak 4,154,357 (3,478,262 Melayu dan 676,095 orang penduduk asal) berbanding etnik Cina, 3,758,048.

Walaupun begitu, penyertaan Sabah dan Sarawak bagi membentuk Malaysia telah mencetuskan reaksi yang pelbagai. Misalnya, Parti Rakyat Sarawak Bersatu (SUPP) menganggap penubuhan Malaysia hanya sebagai pemindahan kuasa British kepada negeri lain, manakala di Sabah juga memperlihatkan 
penentangan oleh Pertubuhan Kebangsaan Kadazan Bersatu (UNKO) dan Pasok Momogun yang meragui terjadinya penjajahan bentuk baharu di wilayah mereka (Mohamad Rodzi 2003). Justeru kebimbangan inilah yang menjadi bibit awal tercetusnya federalisme asimetri dalam struktur persekutuan di Malaysia. Ini kerana bagi mengatasi kekhuatiran terhadap kelangsungan wilayah Sabah dan Sarawak dalam Malaysia, Suruhanjaya Cobbold yang ditubuhkan pada tahun 1962 bagi meneliti pandangan dan pendapat rakyat Sabah dan Sarawak tentang penubuhan Malaysia akhirnya telah mewujudkan Inter-Governmental Committee Report (ICG) pada tahun 1963 yang memperuntukkan perlindungan dan keistimewaan hak, status, dan kedudukan kepada Sabah dan Sarawak melalui peruntukan Perkara 20 dan Perkara 18 dalam perlembagaan. Persetujuan kepada perlindungan dan hak istimewa kepada dua wilayah inilah kemudiannya membentuk struktur asimetri dalam federalisme Malaysia melalui penggubalan Akta Malaysia 1963 dengan pindaan Perlembagaan Persekutuan Tanah Melayu 1957 yang menggabungkan Persekutuan Tanah Melayu, Singapura, Sabah, dan Sarawak pada 16 September 1963 (Singapura berpisah pada tahun 1965) melalui penubuhan Persekutuan Malaysia.

Justeru pembentukan federalisme asimetri dalam Persekutuan Malaysia memperlihatkan pertimbangan nilai dan identiti etnisiti dalam dua keadaan. Pertama penggabungan Sabah dan Sarawak secara historikalnya adalah untuk menyeimbangkan komposisi etnik antara Melayu dan Cina. Kedua, sebagai jaminan kelangsungan Sabah dan Sarawak dalam Persekutuan Malaysia, identiti kewilayahan keduaduanya turut menjadi pertimbangan utama dalam pemberian status dan kedudukan istimewa dalam perlembagaan. Hal ini jelas menunjukkan bahawa etnisiti turut mempengaruhi pembentukan struktur federalisme asimetri di Malaysia melalui pindaan dan peruntukan perlembagaan. Bagi mengukuhkan ciri federalisme ini, beberapa sarjana turut menyatakan hal yang sama seperti Burgess (2006:222) di mana beliau menyatakan, “... asymmetrical practices have also been successful in Malaysia where the two Borneo states of Sabah and Sarawak have enjoyed constitutional asymmetry since 1963..." Watts (2008:127) juga menyatakan, "The most sustained example of this approach (constitutional asymmetry) has been the concessions made to the Borneo states when they joined the Malaysian federation in 1963". Maka, pemberian kedudukan istimewa kepada Sabah dan Sarawak sebagai jaminan penyertaannya dalam Malaysia telah menjadikan kedua-dua wilayah ini lebih berautonomi berbanding 11 unit persekutuan yang lain.

Ini kerana selain boleh menentukan agama dan bahasa rasmi tersendiri, mengawal kewangan dan perkhidmatan awam di samping mempunyai persamaan status serta kedudukan istimewa dengan etnik Melayu berdasarkan Perkara 161A dan Perkara 153, Sabah dan Sarawak juga merupakan dua wilayah eksklusif yang mempunyai autonomi penuh dalam bidang imigresen. Dengan ini, kedua-dua wilayah berkuasa untuk mengawal kemasukan warga Semenanjung dan mensyaratkan warga Semenanjung untuk mendapatkan permit bagi melindungi populasi penduduk asal Sabah dan Sarawak daripada migrasi berlebihan warga Semenanjung. Selain itu, Kanun Tanah Negara 1965 dan Akta Kerajaan Tempatan 1976 yang digubal bagi mewujudkan keseragaman undang-undang kepada setiap kerajaan negeri adalah tidak terpakai kepada Sabah dan Sarawak seperti yang termaktub dalam Perkara 95D. Tidak hanya itu, kedua-dua wilayah ini juga diberi kuasa perundangan tambahan berkenaan cukai jualan seperti yang termaktub dalam Perkara 95B(3) yang memperuntukkan badan perundangan Negeri Sabah dan Sarawak boleh membuat undang-undang bagi mengenakan cukai jualan (Perlembagaan Persekutuan 2020). Begitu juga dengan Perkara 112C(3) yang mengecualikan duti eksport ke atas mineral yang dihasilkan di Sabah dan Sarawak, sedangkan Perkara 110(3A) memperuntukkan bahawa setiap negeri hendaklah menerima syarat yang ditetapkan di bawah undangundang persekutuan, apa-apa perkadaran yang ditetapkan daripada duti eksport atas mineral yang dikeluarkan di dalam negeri itu (Perlembagaan Persekutuan 2020). Tambahan pula, Perkara 161B juga menyekat hak bukan pemastautin untuk menjalankan amalan di hadapan mahkamah dalam negeri Sabah dan Sarawak (Perlembagaan Persekutuan 2020).

Jika unsur etnisiti, iaitu 'Malay cultural dominance' mendominasi pembentukan federalisme Malaysia ke arah terpusat, maka nilai etnisiti khususnya identiti kewilayahan Sabah dan Sarawak terus mempengaruhi perkembangan federalisme Malaysia dan menjadi pertimbangan utama dalam pembentukan asimetri perlembagaan. Justeru sifat asimetri inilah yang dilihat berperanan dalam mewujudkan sentimen nasionalisme tempatan melalui slogan seperti 'Sabah for Sabahan' atau 
'Sarawak for Sarawakian' yang melahirkan perjuangan politik berasaskan parti tempatan melalui Parti Bersatu Rakyat Sabah (PBRS), Parti Pesaka Bumiputera Bersatu (PBB) dan lainnya.

\section{Malaysia Sebagai Federalisme Multi-Etnik}

Federalisme multi-etnik merupakan sebuah modifikasi konsep federalisme di mana federalisme bukan sahaja dilihat sebagai sistem yang membahagikan kuasa antara dua peringkat kerajaan (Wheare 1946), tetapi juga sebagai sistem politik yang menampung elemen perbezaan, kerencaman dan kepelbagaian etnik masyarakatnya. Antara sarjana yang meneliti konsep federalisme multi-etnik adalah Gagnon (2007:18) yang mencirikannya sebagai sebuah sistem politik yang menampung deep diversity (perbezaan etnik, agama, bahasa, dan budaya) untuk mewujudkan kestabilan. Pinder (2007:1) pula menyatakannya sebagai "a framework that can accommodate and as far as possible resolve some of the most intractable political conflicts of our time: those that stem from competing national visions, whether within or between established states." Burgess (2006) pula mencirikannya sebagai suatu sistem politik yang boleh mengendurkan ketegangan antara kumpulan etnik yang berbeza. Justeru dengan keberadaan etnik yang rencam, federalisme multi-etnik dilihat berfungsi dengan dua objektif, iaitu mengiktiraf kepelbagaian etnik agar setiap etnik bebas mengamalkan identiti masing-masing (diversity) serta mewujudkan perpaduan dalam kalangan multi etnik (unity).

Ketika unsur 'Malay cultural dominance' menjadi pertimbangan utama dalam penggubalan perlembagaan di awal kemerdekaan 1957 melalui pelaksanaan diskriminasi perlindungan kepada orang Melayu, kebanyakan sarjana menyatakan hal ini telah pun mencetuskan sifat pembahagian atau perkumpulan dalam kalangan etnik dan implikasinya telah mengurangkan nilai kebersamaan dalam kalangan etnik nasional (Stockwell, 1982). Walau bagaimanapun, kebanyakan perbincangan kronologi sejarah menggariskan bahawa peruntukan diskriminasi perlindungan ini asalnya merupakan peruntukan sementara, di mana Suruhanjaya Reid ketika merangka draf perlembagaan 1957 bersetuju bahawa keistimewaan tersebut perlu disemak semula selepas tempoh 15 ke 20 tahun di parlimen sama ada untuk meneruskan atau menghentikannya (Ratuva, 2013). Namun begitu, belum sempat untuk melakukan semakan semula terhadap peruntukan tersebut, Malaysia mengalami trauma nasional (Ang \& Whiting 2014), iaitu peristiwa 13 Mei 1969. Implikasi peristiwa ini bukan sahaja menyebabkan semakan semula peruntukan tersebut diketepikan, malah diskriminasi perlindungan ini terus diperkukuhkan. Buktinya, kerajaan pusat memperkenalkan Dasar Ekonomi Baru (DEB) pada tahun 1971 yang meluaskan lagi jaminan, perlindungan, dan kedudukan istimewa Melayu khususnya dalam sektor pelaburan, pemilikan modal, dan pendidikan (Chakraborti, 1996). Bagi Crouch (1996:27), "...the new policy clearly favored Malays at the expense of non-Malays..." Pelaksanaan dasar ini menunjukkan kerajaan pusat yang sepatutnya menjadi aktor pengimbang dalam federalisme multi etnik disebabkan punca tercetusnya trauma nasional ini mempunyai kaitan dengan isu ketidakseimbangan taraf kehidupan dan kemiskinan antara etnik, namun sebaliknya kerajaan pusat lebih memihak kepada satu etnik dalam pembuatan polisi nasional. Disebabkan hal inilah, Crouch (2001:230) berhujah tahun 1960-an memperlihatkan kebanyakan dasar kerajaan pusat dipengaruhi oleh etnisiti yang merangkumi aspek bahasa, pendidikan, kerajaan, pekerjaan, permit dan lesen perniagaan, imigrasi, keselamatan dalaman, dan dasar luar. Justeru pengaruh kuat nilai etnisiti tidak hanya menyerlahkan ciri multi-etnik dalam federalisme Malaysia, malah kerajaan pusatnya turut direfleksi dengan terma-terma seperti 'ethnocracy' dan 'ethnocratic state' (Wade, 2014).

Dalam meneliti pengaruh etnisiti dalam federalisme multi etnik Malaysia dengan lebih terperinci, Mohd Shamsul (2003) menggariskan empat aspek polisi yang dipengaruhi kuat oleh etnisiti, iaitu (i) politik dan pemerintahan, (ii) ekonomi dan perniagaan, (iii) pendidikan dan bahasa, dan (iv) agama dan budaya. Dalam aspek politik dan pemerintahan, beliau menyatakan selain pengaruh etnisiti wujud dalam pembentukan parti politik, bidang perkhidmatan awam turut menerima pengaruh etnik apabila latar historikal menunjukkan bahawa Malayan Civil Service pada tahun 1952 memperuntukkan penglibatan Melayu dan bukan Melayu masing-masing dalam nisbah 4:1. Disebabkan inilah, Melayu kekal mendominasi jawatan-jawatan senior dalam pentadbiran di samping mengisi institusi-institusi utama pentadbiran seperti dalam badan perundangan, kabinet kerajaan, birokrasi, pertahanan, polis, dan kehakiman. Misalnya, pada tahun 1970, peratusan etnik Melayu dalam pasukan tentera dan polis 
meningkat daripada 70\% kepada 86\% pada tahun 1980 (Ratuva, 2013:202). Dalam aspek ekonomi dan perniagaan pula, pengaruh etnisiti dapat dilihat pada tahun 1975 apabila kerajaan pusat memperkenalkan Akta Penyelarasan Perindustrian yang mensyaratkan syarikat bukan Melayu yang mempunyai modal dan simpanan dana bernilai lebih RM250,000 dengan tenaga kerja yang melebihi 25 orang, perlu mempunyai sekurang-kurangnya $30 \%$ pemilikan atau penyertaan Bumiputera jika ingin lesen perniagaan mereka diperbaharui dan kerajaan boleh menafikan pengeluaran lesen kepada mana-mana syarikat bukan Melayu yang tidak memenuhi syarat tersebut.

Selain itu, kerajaan pusat juga tidak hanya mewujudkan institusi seperti Komuniti Komersial dan Perindustrian Bumiputera, Majlis Amanah Rakyat (MARA), Bank Bumiputra, Perbadanan Nasional Berhad (PERNAS), dan Perbadanan Pembangunan Ekonomi Negeri untuk menyediakan bantuan kredit dan teknikal kepada usahawan dan peniaga Melayu, malah ia juga meminta syarikat perniagaan besar untuk mempromosikan kenaikan pangkat dalam jawatan pengurusan yang lebih tinggi kepada Melayu. Begitu juga dalam aspek pendidikan dan bahasa, beliau menyatakan bahawa selepas peristiwa Mei 1969, kerajaan tidak hanya memperkenalkan pindaan perlembagaan 1971 yang memberi kuasa kepada Raja untuk menetapkan kuota kemasukan dalam pendidikan tinggi, tetapi ia juga menubuhkan dua universiti, iaitu Universiti Kebangsaan Malaysia dan Universiti Islam Antarabangsa yang kebanyakannya disediakan untuk orang Melayu, namun kemasukan bukan Melayu diperuntukkan dalam jumlah tertentu.

Dalam aspek agama dan budaya pula, beliau juga menyatakan bahawa kerajaan pusat didakwa menjalankan proses Islamisasi secara aktif melalui pelbagai beberapa program dan institusi. Contohnya dengan menubuhkan Bank Islam, pengembangan bidang kuasa Mahkamah Syariah, dan penyediaan peruntukan besar dalam pembinaan masjid berbanding rumah ibadat agama lain (Mohd Shamsul, 2003:246-251). Pertimbangan etnisiti dalam aspek-aspek di atas menunjukkan pengaruhnya hampir merangkumi setiap aspek kehidupan rakyat. Justeru hal ini berupaya mengekalkan kewujudan 'ethnic division' dalam hubungan multi etnik kerana keberadaan pengaruh etnisiti terutamanya dalam aspek-aspek kehidupan asas dari satu sisi menggambarkan betapa kurangnya nilai yang boleh dikongsi dan mengikat etnik secara bersama. Implikasi perkara ini cenderung mencetuskan dikotomi hubungan 'Melayu vs bukan Melayu' untuk suatu tempoh masa panjang yang semestinya tidak baik kepada kelangsungan federalisme multi etnik kerana ia boleh mencetuskan konflik etnik dan menggugat kestabilan persekutuan.

Justeru perbincangan di atas menunjukkan bahawa nilai dan identiti etnisiti akan terus kekal mempengaruhi dan menjadi pertimbangan utama dalam proses dan perkembangan sistem politik persekutuan kontemporari yang akhirnya membentuk Malaysia sebagai sebuah federalisme multietnik.

\section{Kesimpulan}

Perbincangan dalam artikel ini menghujahkan persekutuan Malaysia telah berkembang melalui tiga tahap federalisme, iaitu sebagai federalisme terpusat, federalisme asimetri, dan federalisme multi etnik. Perkembangan ini berlaku kerana dipengaruhi kuat oleh faktor etnisiti. Ini kerana latar historikalnya memperlihatkan tingginya sentimen nasionalisme Melayu sebagai etnik majoriti dan penduduk asal Tanah Melayu yang berusaha, berjuang, dan mempertahankan identiti etnik mereka secara berterusan melalui pelbagai organisasi (parti, badan sivil dan separa politik) dalam politik dan kerajaan Malaysia. Disebabkan hal ini, etnisiti terus mempengaruhi perkembangan kontemporari hubungan multi etnik dalam federalisme Malaysia.

Implikasinya menyebabkan simbol, nilai, dan tradisi etnik Melayu diterjemahkan dalam dasar negara, kebudayaan sosial dan aspirasi nasional. Selain itu, kesannya juga boleh mengimpak keharmonian hubungan etnik antara Melayu dan bukan Melayu serta menjejaskan perpaduan antara Semenanjung dengan Sabah dan Sarawak. Akhirnya, walaupun etnisiti Melayu kuat mempengaruhi perkembangan tahap historikal dam kontemporari federalisme Malaysia, namun hal ini tidak mewujudkan sentimen 
nasionalisme sempit etnik majoriti Melayu/Bumiputera. Ini kerana etnik Melayu/Bumiputera umumnya menerima, menghormati dan tidak menafikan hak dan kedudukan kumpulan etnik minoriti.

\section{Penghargaan}

Penulisan ini sebahagiannya dibiayai oleh Kementerian Pengajian Tinggi Malaysia melalui Skim Geran Penyelidikan Fundamental (FRGS/1/2020/SS0/UKM/02/3).

\section{Rujukan}

Adeney, K. \& Bhattacharyya, H. (2018). Current challenges to multinational federalism in India. Regional and Federal Studies, 28(4), 409-425.

Ang, H. L. \& Whiting, A. (2014). Federalism and legal unification in Malaysia. In D. Halberstam \& M. Reimann (Eds.), Federalism and legal unification: A comparative empirical investigation of twenty systems (pp. 295-337). Dordrecht: Springer.

Bakar, I. (2007). Multinational federation: The case of Malaysia. In M. Burgess \& J. Pinder (Eds.), Multinational federations (pp. 68-85). London and New York: Routledge.

Bhattacharyya, H. (2010). Federalism in Asia: India, Pakistan and Malaysia. Abingdon, Oxon: Routledge.

Burgess, M. (2006). Comparative federalism: Theory and practice. Abingdon, Oxon: Routledge.

Case, W. (2016). Feckless federalism in Malaysia. Dalam Hofmeister, W. \& Tayao, E. (sunt.). Federalism and decentralization: Perceptions for political and institutional reforms (pp. 165188). Singapore: Konrad Adenauer Stiftung.

Chakraborti, T. (1996). The New Economic Policy of Malaysia: Its Impact on the Malaysian Indians. Jadavpur Journal of International Relations, 2(1), 193-205.

Chin, J. (2019). The 1963 Malaysia Agreement (MA63): Sabah and Sarawak and the politics of historical grievances. In S. Lemiere (Ed.), Minorities matter: Malaysians politics and people (pp. 75-92). Singapore: ISEAS-Yusuf Ishak Institute.

Crouch, H. (1996). Government and Society in Malaysia. Allen \& Unwin: Cornell University Press.

Crouch, H. (2001). Managing ethnic tensions through affirmative action: The Malaysian experience. In N. J. Colletta, T. G. Lim, \& A.Kelles-Viitanen (Eds.), Social cohesion and conflict prevention in Asia (pp. 225-262). Washington, DC: The World Bank.

Fong, J. C. (2016). Constitutional federalism in Malaysia: Second edition. Malaysia: Sweet \& Maxwell.

Gagnon, A.G. (2007). Democratic multinational federalism under scrutiny: Healthy tensions and unresolved issues in Canada. In M. Burgess \& J. Pinder (Ed.), Multinational federations (pp. 1730). New York: Routledge.

Harding, A. J. \& Chin, J. (2014). 50 years of Malaysia: Federalism revisited. Singapore: Marshall Cavendish Editions.

Ishak Saat. (2010). Caturan Politik Pelbagai Kaum di Tanah Melayu, 1946-1957. Jebat, 37, 68-85.

Loh, F. K. W. (2010). Restructuring federal-state relations in Malaysia: From centralised to cooperative federalism? The Round Table: The Commonwealth Journal of International Affairs, 99(407), 131-140.

Milne, R. S \& Mauzy, D. K. (1978). Politics and government in Malaysia. Singapore: Federal Publications (S) Pte Ltd.

Mohammad Agus Yusoff. (2006). Malaysian federalism: Conflict and Consensus. Bangi: Penerbit Universiti Kebangsaan Malaysia.

Mohamad Rodzi Abd Razak. (2003). Gagasan Malaysia dan Penglibatan British: Satu Tinjauan, Jebat, $29,109-122$.

Mohd Shamsul Haque. (2003). The Role of the State in Managing Ethnic Tensions in Malaysia: A Critical Discourse. American Behavioral Scientist, 47(3), 240-266.

Morrison, I. (1949). Aspects of the racial problem in Malaya, Pacific Affairs, 22(3), 239-53.

Pinder, J. (2007). Multinational federations: Introduction. In M. Burgess \& J. Pinder (Eds.), Multinational federations (pp. 1-16). New York: Routledge. 
DOI: https://doi.org/10.47405/mjssh.v6i11.1139

Ratuva, S. (2013). Politics of preferential development: Trans-global study of affirmative action and ethnic conflict in Fiji, Malaysia and South Africa. Canberra: The Australian National University.

Rudner, M. (1976). The structure of government in the colonial federation of Malaya. South East Asian Studies, 13(4), 495-512.

Salleh, A., Puyok, A. \& Bagang, T. P. (2019). Constitutional asymmetry in Malaysia: A case study of Sabah and Sarawak. A country study of constitutional asymmetry in Malaysia. In Popelier, P. \& Sahadzic, M. (Eds.). Constitutional asymmetry in multinational federalism: Managing multinationalism in multi-tiered systems (pp. 315-340). Switzerland: Palgrave Macmillan.

Shafruddin, B. H. (1987). The federal factor in the government and politics of Peninsular Malaysia. Singapore: Oxford University Press.

Simandjuntak, B. (1969). Malayan federalism, 1945-1963: A study of federal problems in a plural society. Kuala Lumpur: Oxford University Press.

Stockwell, A. J. (1982). The White Man's Burden and Brown Humanity: Colonialism and Ethnicity in British Malaya. Asian Journal of Social Science, 10(1), 44-68.

Tan Liok Ee. (1995). The Politics of Chinese Education in Malaya, 1946-1961. Kuala Lumpur: Oxford University Press.

Tarlton, C. D. (1965). Symmetry and Asymmetry as Elements of Federalism: A Theoretical Speculation, The Journal of Politics, 27(4): 861-874.

Wade, G. (2014). The origins and evolution of ethnocracy in Malaysia. Dalam Lemier, S. (Ed.). Misplaced democracy: Malaysians politics and people. Petaling Jaya: Strategic Information and Research Deveopment Centre.

Watts, R. L. (2008). Comparing federal systems: Third edition. Montreal \& Kingston: McGillQueen's University Press.

Wheare, K. C. (1946). Federal government. London: Oxford University Press.

Wong, C. H. \& Chin, J. (2011). Malaysia: Centralized federalism in an electoral one-party state. In R. Saxena, Varieties of federal governance: Major contemporary models (pp. 208-231). Cambridge: Cambridge University Press.

Yeo, K. W. (1973). The Anti-Federation Movement in Malaya, 1946-48. Journal of Southeast Asian Studies, 4(1), 31-51. 